\title{
Wertykalna izolacja. Górska proza Tadeusza Piotrowskiego
}

\section{Przemyseaw Kaliszuk}

ORCID: 0000-000I-8668-39II

(Uniwersytet Marii Curie-Skłodowskiej w Lublinie)

I.

Zainteresowanie górami łączy się bezpośrednio z nowoczesnymi przekształceniami rzeczywistości ${ }^{\mathrm{I}}$. Człowiek zaczął spoglądać na przestrzenie górskie śmielej, widząc w nich zachętę do aktywności innych niż estetyczny podziw lub kontemplacja ${ }^{2}$. Szczyty gór, uwodząc pięknem i niedostępnością, stawały się wyzwaniami rzuconymi ludzkości³ ${ }^{3}$ Kwintesencją tego procesu była słynna i wielokrotnie powtarzana sentencja George'a Mallory'ego dotycząca powodu zdobywania Everestu „Ponieważ istnieje”4. Wypowiedź Brytyjczyka dotyka również innej ważnej kwestii - komunikacyjnego oporu, jaki stawiają przestrzenie górskie będące terenami nowoczesnej eksploracji. Mallory nie wdaje się w szczegóły i lakonicznie omija zawartą w pytaniu dziennikarza prośbę o urealnienie przeżyć i motywacji osamotnionego wspinacza. Jednocześnie bagatelizując to, sygnalizuje własne kłopoty z wyrażalnością oraz antycypuje problemy swoich następców w kolejnych dekadach XX wieku. Daje tu o sobie znać charakterystyczne napięcie między potrzebą komuni-

1 E. Roszkowska, Taternictwo polskie. Geneza i rozwój do 1914 roku, Kraków 2013, s. $19-45$.

2 Zob. R. Macfarlane, Mountains of the Mind. A History of a Fascination, London 2018.

3 M. Isserman, S.A. Weaver, Upadek olbrzymów. Historia wspinaczek bimalajskich od epoki imperiów do epoki skrajności, tłum. M. Młynarz, Oświęcim 2019, s. 41-48; E. Mazzolini, The Everest Effect. Nature, Culture, Ideology, Tuscaloosa 2015, s. 1-20.

4 G. Mallory, Climbing Mount Everest Is Work for Supermen [wywiad], „The New York Times”, 18 marca 1923; zob. M. Pacukiewicz, Grañ kultury. Transgresje alpinizmu, Kraków-Katowice 2012, s. 8-11; W. Davis, Into the Silence. The Great War, Mallory, and the Conquest of Everest, New York 2012, s. 467468. 
kacji a specyficzną, przestrzenną i poznawczą izolacją - ukonkretnieniu doświadczeń alpinisty towarzyszy niemożność nazwania tego, co intymnie przeżywane, komplikując proces mediacji.

W polskim kontekście góry (przede wszystkim Tatry jako najwyższe pasmo) wkraczają w sferę zbiorowej wyobraźni w XIX wieku', a od początków XX stulecia oddziałują intensywniej na kolejne pokolenia badaczy, przyrodników, wspinaczy. Jest to czas poszerzania zakresu aktywności górskich, w tym wspinaczki - kluczowej dla ukonstytuowania się rozmaitych dyskursów pisarskich. Ze stale poszerzającym się spektrum praktyk sportowych, turystycznych i przyrodniczych w obrębie Tatr łączą się procesy instytucjonalizacji, prowadzenia debat, poszukiwania uzasadnień programowo-teoretycznych i wypracowywania regulacji prawnych. Tworzy się swego rodzaju dyskursywne wrzenie, które angażuje kwestie badań naukowych, ochrony przyrody, turystyki, etnografii, taternictwa, co oddziałuje w szerszym kontekście na konceptualizacje w obrębie literatury fikcjonalnej i użytkowej. Doświadczenia górskie, w swej istocie głęboko nowoczesne, stopniowo wypracowują własną gamę adekwatnych środków narracyjnych i form gatunkowych, które z perspektywy górołazów będą dawać satysfakcjonujące rezultaty. Ów proces formowania się literatury górskiej $^{6}$ (tego, co w kręgu anglojęzycznym określa się jako mountaineering literature) przebiegał w warunkach polskich ciekawie - opozycyjnie wobec stymulującej ją literackości wczesnego modernizmu, premiując „aliterackość” zdeterminowaną przez doświadczenie przestrzeni górskiej: pisanie o górach było usankcjonowane doświadczeniem bycia (wędrówki, wspinaczki), choć wcześniej to status pisarza dawał możliwość zrelacjonowania doświadczeń górskich - jak dowodzi przypadek literatury młodopolskiej 7 .

W pierwszych dekadach XX wieku tworzyła się i ewoluowała literatura funkcjonująca w określonym obiegu, $\mathrm{z}$ jednej strony - fachowa o znamionach użytkowych, z drugiej - stopniowo zdobywająca miejsce wśród obszernej kategorii tekstów niefikcjonalnych, wkraczająca do głównego obiegu kultury wraz ze wzrostem zainteresowania wspinaczką, alpinizmem i himalaizmem ${ }^{8}$, które są zresztą charakterystycznymi emanacjami dynamicznego wiru nowoczesności. Jednocześnie punktem stycznym $z$ literaturą głównego nurtu modernizmu była kwestia poszukiwania satysfakcjonujących narzędzi ekspresji realności ${ }^{9}$, która dla twórców prozy górskiej

5 E. Roszkowska, Taternictwo polskie..., s. 59-72; J. Kolbuszewski, Tatry w literaturze polskiej. Cz. 1-2, Kraków 1982, s. 231-244.

6 T. Stępień, Przestrzeń w literaturze „górskiej”, w: Od poetyki przestrzeni do geopoetyki, red. E. Konończuk, E. Sidoruk, Białystok 2012, s. 87-102.

7 J. Kolbuszewski, Tatry w literaturze..., s. 581-615.

8 Por. idem, Literatura i Tatry. Studia i szkice, Zakopane 2016, s. 641-657.

9 Idem, Góry-przestrzenie i krajobrazy. Studia z historii literatury i kultury, Kraków 2020, s. 239-264. 
oznaczała - ujmując rzecz dość ogólnie - sferę trudnych do uchwycenia, zdefiniowania i uzasadnienia relacji człowieka z przestrzeniami (wysoko)górskimi, czemu towarzyszy przymus artykulacji tej strefy. Owe relacje (a w zasadzie próby ich nazywania i opisania) kształtują skomplikowaną topografię realności pisarstwa górskiego, w którym powtarzają się: pragnienie i zarazem kult autentyczności, gloryfikowanie dokumentalności, nobilitowanie szczerości, doświadczanie wzniosłości, ale również troska o podmiotowość „ja-w-górach”. Osobista perspektywa pisania stawała się domyślnym trybem opowieści górskich ze względu na dojmującą potrzebę wyrażenia, a równocześnie uporządkowania tych nowych afektów i doświadczeń rodzących się w warunkach wertykalnej izolacji górołaza, który początkowo - pozostawał figurą trudną do odczytania z uwagi na elitarność alpinizmu jako praktyki wąskiego grona fachowców. Autobiograficzność ${ }^{\mathrm{IO}}$, pozostaje pewnym wymogiem w obrębie literatury górskiej ${ }^{\text {II }}$, ponieważ pozwala niejako naturalnie tworzyć (chociażby chwilowo) empatyczną wspólnotę między autorem-narratorem a czytelnikiem, abstrahując od tego, czy ów czytelnik jest częścią środowiska górskiego, czy też laikiem spragnionym tajemnic ekstremalnej egzystencji.

2.

Proza Tadeusza Piotrowskiego bez wątpienia wyrasta z tradycji polskiego piśmiennictwa górskiego. Autor, wkraczający w rzeczywistość aktywności górskich w drugiej połowie lat sześćdziesiątych XX wieku, ma do czynienia - jako pisarz-wspinacz z określonym zespołem środków wypracowanych $\mathrm{w}$ obrębie dyskursu prozy górskiej ${ }^{\mathrm{j} 2}$. $\mathrm{Z}$ tego względu w pisarstwie Piotrowskiego ogniskują się charakterystyczne cechy alpinistycznych narracji górskich w ich rozwiniętym stadium. Najważniejsze dla nich pozostają strategia szczerości i koncepcja autentyczności sankcjonujące tekst ${ }^{\mathrm{t3}}$, warunkujące możliwość komunikacji w pisarstwie górskim. Proza taternicka, uprawiana także przez Piotrowskiego, usytuowała się opozycyjnie wobec takich rozwiązań poetologicznych, narracyjnych i stylistycznych, które mogły prowadzić do zbytniej literackości, a ostatecznie zagrażały ufikcyjnieniem opowieści i zafałszowaniem

10 P. Lejeune, Wariacje na temat perwnego paktu. O autobiografi, red. R. Lubas-Bartoszyńska, tłum. W. Grajewski et al., Kraków 2007, s. 1-19; M. Beaujour, Autobiografia i autoportret, tłum. K. Falicka, w: Autobiografia, red. M. Czermińska, Gdańsk 2009; S. Smith, J. Watson, Reading Autobiography. A Guide for Interpreting Life Narratives, Minneapolis-London 2001, s. 1-14.

11 Por. M. Pacukiewicz, Literatura alpinistyczna jako „sobapisanie”, „Napis” 2010, seria 16, s. 495-511.

12 Z. Tumidajewicz, ...o polskiej literaturze alpinistycznej, „Bularz” 1991, s. 106-111.

13 Zob. E. van Alphen, M. Bal, Introduction, w: The Rhetoric of Sincerity, red. E. van Alphen, M. Bal, C.E. Smith, Stanford 2009, s. 1-16; T. Milnes, K. Sinanan, Introduction, w: Romanticism, Sincerity and Authenticity, red. T. Milnes, K. Sinanan, London 2010. 
perspektywy. Taternicy, dokonujący śmielszych przejść, zdobywający liczne szczyty, byli poniekąd skazani na swoistą autoizolację kulturową ze względu na ekskluzywność własnej aktywności. Mierzyli się zatem z problemem ujmowania w słowa jednostkowych przeżyć zarówno w kontekście doświadczeń innych wspinaczy, jak i w kontekście możliwości percepcyjnych ludzi niezaznajomionych z górami, dla których niezrozumiała pozostawała sama chęć narażania życia i zdobywania stromych wierzchołków ${ }^{\text {I4 }}$. Okazało się, że istotą doświadczenia górskiego jest konceptualny i dyskursywny opór, jaki stawia ono podmiotowi pragnącemu je wysłowic ${ }^{15}$, przy czym doświadczającemu ,ja” towarzyszy poczucie swoistej konieczności znalezienia (lub zbudowania) odpowiedniej, to znaczy autentycznej i szczerej, strategii komunikacyjnej, zdolnej przekazać unikalność, a także nowość doświadczenia górskiego, rodzącego się w drodze nowoczesnych przemian rzeczywistości. Autentyczność i szczerość zyskują postać niezbędnych wymogów, ponieważ jedynie osobista perspektywa uprawnia do pisania o doświadczeniach specyficznych dla wspinaczki, a szerzej: bycia w górach, nawet jeśli taka komunikacja przekształci się finalnie w obiektywną relację $\mathrm{w}$ typie książki wyprawowej ${ }^{\mathrm{T}}$ czy oficjalnej notki prasowej. W ten sposób pisanie górskie zyskiwało stopniowo wymiar autobiograficzny, zaś modernistyczne kategorie szczerości i autentyczności przekształcały się w „filtry” pozwalające ocenić prawdziwość opowieści, a więc adekwatność wyłaniającej się z tekstu realności.

Teksty Tadeusza Piotrowskiego okazują się ciekawe właśnie ze względu na proces asymilacji odrzucanej czy funkcjonującej w ograniczonym zakresie w literaturze górskiej literackości ${ }^{17}$, niejako domyślnie usytuowanej w sferze podejrzenia w kontekście wzorcowej dlań dokumentalności. Są też interesujące z innego powodu. Pozwalają spojrzeć na centralną w takich opowieściach kwestię relacji między podmiotem (najczęściej autorefleksyjnym) a przeżywaną i doświadczaną przezeń specyficzną przestrzenią, która warunkuje wszelkie próby idiomatycznych bądź uniwersalizujących konceptualizacji samej siebie ${ }^{\mathrm{I} 8}$, ale również - co może ważniejsze - warunkuje autokonceptualizacje podmiotu zmuszonego w obliczu zetknięcia się z orosferą do wypracowania wizji siebie ${ }^{\mathrm{I} 9}$.

14 H. Jarzębowski, Bajdurzyć, czyli mórwić prawdę, „Góry” 2013, nr 9 (232).

15 Por. A. Matuszyk, Czy ideologia jest koniecznie do wspinania potrzebna? (Kilka stów o istocie i funkcjach ideologii wspinaczkowych), w: Materiaty z teorii i dydaktyki sportów wspinaczkowych. Z. 2, red. A. Matuszyk, Kraków 1993, s. 105-122.

16 D. Hołata, O pochodzeniu ksiqżki wyprawowej, „Bularz” 1991, s. 73-84.

17 M. Okupnik, Autobiografie polskich sportowców samotników, Gniezno 2005, s. 149-158.

18 Por. J. Lester, Spirit, Identity, and Self in Mountaineering, ,Journal of Humanistic Psychology” 2004, t. 44 , nr 1, s. 86-100.

19 M. Pacukiewicz, Grań kultury..., s. 234-247. 
W twórczości Piotrowskiego wyrazista staje się konstelacja dialektycznych napięć między: autobiografią i zapisem wertykalnego ruchu w otoczeniu górskim, cielesno-zmysłową konkretnością i zapośredniczeniem reprezentacji językowo-figuratywnej (opowieści, listy, opisy, ekfrazy, fotografie, szkice, mapy, cytaty), narracyjnymi strukturami porządkującymi i pozornie neutralnym dokumentaryzmem, subiektywnością perspektywy i tendencją do obiektywizacji. Wspomniana konstelacja definiuje i determinuje istotę nowoczesnych narracji górskich zmagających się - świadomie i nieświadomie - z własnym statusem, określanym przez liczne opozycje w obrębie kultury nowoczesnej.

Piotrowski opisuje wspinaczkowe przygody z Tatr, Alp, rejonu norweskiej doliny Romsdalen, Karakorum, Hindukuszu i Pamiru. Stopniowo, z upływem lat zbliża się do gór wysokich - przestrzeni trudnych ze względu na warunki pogodowe i topograficzne oraz niezbędne umiejętności i predyspozycje. Książki są zapisem tego procesu przechodzenia do coraz bardziej wymagających celów eksploracyjnych i alpinistycznych. Trajektoria rozwoju wspinaczkowego domyślnie określa logikę wydawniczą, choć wkracza tutaj jeszcze jeden czynnik - poszukiwanie własnego dyskursu pisarskiego, zdeterminowanego przez zastaną tradycję narracji górskich.

3.

Twórczość Piotrowskiego ma wyraźnie autobiograficzny charakter. Alpinista opowiada o wspinaczkach i wyprawach, w jakich brał udział, przyjmując osobisty punkt widzenia. To on stanowi zasadniczą instancję nadawczą, która gwarantuje szczerość i rzetelność przedstawianych wydarzeń. Opisywane historie są pokaźną częścią życiorysu Piotrowskiego, uporządkowanego przez poszczególne opowieści. Ich podmiot stale sygnalizuje, że jest tożsamy z Tadeuszem Piotrowskim, w zasadzie na początku każdej narracji zawiera podstawowy pakt - pakt autobiograficzny ${ }^{20}$ wyznaczający porządek konstruowanej historii, gwarantujący jej autentyczność dzięki swoistemu autozobowiązaniu do szczerości (jest to charakterystyczne dla prozy górskiej), a więc umowę mającą wymiar etyczny - presuponowane przyrzeczenie prawdomówności. Wyłącznie doświadczenie (aktywność i praktyka) uprawnia do snucia narracji. Metateksty otwierające książki Piotrowskiego są pełne takich rytualnych zapewnień i poświadczeń, będących też sygnałami autobiograficznego kodu, przez które ,ja” dokonuje autoidentyfikacji.

Opublikowany w 1977 roku zbiór $W$ burzy i mrozie rozpoczyna się opowieścią 
inicjacyjną, zaś książka jest rodzajem przewodnika po rzeczywistości alpinistycznej. Wstęp - tekst istotny jako topografia cech poetologicznych twórczości Piotrowskiego - otwiera wyznanie, które ustanawia autobiograficzną umowę:

\section{\Kiedy I4 lipca I964 roku rozpoczynałem swój taternicki terminarz od wejścia na Przełęcz Mylną przez Płytę Lerskiego drogą zakodo- waną jako WHP 85, w najśmielszych nawet marzeniach nie przy- puszczałem, że jest ona początkiem drogi prowadzącej w góry świa- ta. Tamtego pięknego lata ściany tatrzańskie dostarczały takiej dozy wrażeń, że nie było miejsca na nierealne mrzonki. Żyłem Tatrami. Uczyłem się gór ${ }^{2 \mathrm{I}}$.}

Znamienny pozostaje konfesyjny ton wprowadzający relacje bliskości. Piotrowski korzysta $\mathrm{z}$ retoryki szczerości, sięgając po pamięć, co widać w rekonstruującym wspominaniu osobistej przeszłości, i obnażając własne doznania intymne. Zwraca uwagę na przełomowy moment swojej biografii, będący - z późniejszej perspektywy - doświadczeniem formacyjnym, symbolicznym początkiem podmiotowości taternika-alpinisty. Nie mając wystarczających narzędzi ekspresji, lakonicznie ujmuje skalę tegoż doświadczenia, mimowolnie dotykając fundamentalnej własności orosfery. Powiada przecież, że ściany tatrzańskie oddziaływały tak silnie, iż niemal usuwały z pola widzenia wszelkie kwestie, które nie miały związku z ich konkretnością. Piotrowski zapewnia więc o przejmującej totalności doświadczeń górskich, ale także świadomie wskazuje na góry jako katalizator własnej biografii, który daje poczucie tożsamości.

W innym miejscu Wstępu Piotrowski, podsumowując wczesny etap tatrzańskiej edukacji wspinaczkowej, podkreśla nieco konwencjonalnie swoją pozycję wobec przestrzeni wertykalnych. Uderza tu konceptualizowanie fascynacji górskiej przez metaforykę szaleństwa i uzależnienia. Jest to zrozumiałe w obliczu innych aktywności, które dają się zracjonalizować jako „pożyteczne” praktyki kulturowe harmonizujące $\mathrm{z}$ codziennością, choć też zaskakujące w drugiej połowie XX wieku, zważywszy, że same aktywności górskie, a szerzej: góry, stopniowo traciły swoją aurę elitarności i wzniosłości ${ }^{22}$.

\section{\Tak zrodziła się pasja i fascynacja światem gór trwająca po dziś dzień. Góry nieodwołalnie owładnęły mną, wypełniając sobą każdą}


wolną chwilę, jaką udaje się wygospodarować z codziennych obowiązków ${ }^{23}$.

Metaforyka opętania wpisuje się zresztą w problem poszukiwania uzasadnień dla ludzkiej bytności w górach wysokich i najwyższych. Debaty tego rodzaju były szczególnie intensywne w początkowych etapach eksploracji rejonów górskich do połowy XX wieku. Polskie ekspedycje w latach trzydziestych wyruszały więc, aby realizować również cele naukowe ${ }^{24}$. Wspinacze byli kartografami, geologami, biologami, wchodząc w rolę charakterystycznych figur nowoczesności: badacza, odkrywcy, inżyniera czy dewelopera.

Finalne partie Wstępu odnoszą się już do opowieści: celów i motywacji pisania. Znów - są chwytami dosyć konwencjonalnymi, lecz znaczącymi z uwagi na autobiograficzność tekstu. Piotrowski wprost deklaruje, że brał udział w relacjonowanych wydarzeniach, i prezentuje je szerzej, żeby laicy mogli dzięki mechanizmom tekstu zaznać specyfiki i unikalności doświadczenia wertykalnej przestrzeni.

\W burzy i mrozie to opowieść o pięciu przygodach górskich, jakie dane mi było przeżyć na przestrzeni kilku lat w Tatrach, górach Norwegii i Alpach. Są to opowieści o zwycięskich akcjach wspinaczkowych, o pierwszych zimowych przejściach najtrudniejszych dróg w poszczególnych masywach górskich. A zarazem jest to opowieść o współczesnym alpinizmie wyczynowym, o zmaganiach człowieka z pierwotną przyrodą, o walce, jaką świadomie podejmują ludzie w najmniej korzystnych warunkach, aby tym wyraziściej wykazać swój hart i wolę zwycięstwa. [...]

Na kartach tej książki chciałem pokazać Czytelnikowi, jak ogromnego wysiłku wymagają góry od alpinisty, jak niezwykle bezwzględny jest egzamin, który musi zdać. [...]

Zapraszam więc do odbycia wspólnej wspinaczki, do przemierzenia jeszcze raz tras już kiedyś przeze mnie przebytych, do współudziału $\mathrm{w}$ wielkiej przygodzie, której na imię a $1 \mathrm{p}$ i n i z $\mathrm{m}^{25}$.

23 T. Piotrowski, Wburzy i mrozie, s. 7.

24 S. Daszyński, Polska wyprawa alpinistyczno-naukowa w góry Ameryki Potudniowej, „Wierchy” 1934, nr 12, s. 105-126; J.T. Wojsznis, Druga polska wyprawa w Andy 1936/37 r. w potudniowa czesśc Puna de Atacama. Opis wyprawy, „Taternik” 1956, t. 32, nr 3/4, s. 85-110.

T. Piotrowski, W burzy i mrozie, s. 11-12. 
Tadeusz Piotrowski w puencie podnosi problem alpinistycznej narracji górskiej, dla której tekst stanowi (powtórzoną) wspinaczkę. Nie jest to wyłącznie zgrabna figura retoryczna, lecz zasadnicza konceptualizacja ${ }^{26}$. Praktyka wspinaczkowa przez językowe mechanizmy reprezentacji przekształca się w tekstowy, narracyjny ekwiwalent ${ }^{27}$, zaś na piszącym spoczywa etyczne zobowiązanie do rzetelności i troski o skuteczność owej reprezentacji, która rodzi się dzięki dystansowi i pozostaje wtórna wobec doświadczenia. W tekście zamykającym tom $W$ burzy $i$ mrozie Piotrowski, akcentując nieodzowność dystansu czasowego i emocjonalnego jako warunku przepracowania przeżyć, dodaje:

\section{\Mogłem [...] spokojnie pracować nad książką; spojrzeć z zewnątrz, bez tego ogromnego zaangażowania emocjonalnego, które jest nie- odłącznym towarzyszem każdej wspinaczki, każdego wyjazdu w góry. Miałem więc czas na przemyślenia, na zabawy z córeczką, na spokoj- ne życie rodzinne ${ }^{28}$.}

Oprócz tych metatekstowych uwag książka definiuje się jako proza górska, wzmacniając autobiograficzne sygnały, dzięki wykorzystaniu narzędzi dokumentacyjnych: datowaniu poszczególnych opowieści oraz fotografii. Owym opowieściom towarzyszy ponadto komponent encyklopedyczny, dodatkowo potwierdzający kompetencje autora oraz wzmacniający pakt autobiograficzny. Komponent ten tworzą: aneksy dotyczące osiągnięć wspinaczkowych w rejonie Kazalnicy Mięguszowieckiej w Tatrach (kontekst dla pierwszego opowiadania), polskiego alpinizmu zimowego w Alpach (faktograficzne dopełnienie kolejnej opowieści) i w Norwegii (pozostałe teksty tomu traktują o górach norweskich) oraz słownik pojęć alpinistycznych, który także jest narzędziem weryfikacji wiedzy i kompetencji autora, pozwalającym przy okazji rozwikłać specyfikę socjolektalną pisania górskiego, jak również zniwelować elitarność.

Gdy krzepnie rtęć ${ }^{29}$ - opowieść o zimowej wyprawie na Noszak w Hindukuszu ma nieco inny charakter, ponieważ proponuje odmienny tryb autobiograficznego legitymizowania zasadności własnej opowieści. „Ja” jest alpinistą, uczestniczącym w kolejnej wyprawie, która trwa, i wprowadzającym w środek wydarzeń. Narracja chwyta tę procesualność, by zasymulować afektywny stan współuczestnictwa. Istotne

26 P.A. Nettlefold, E. Stratford, The Production of Climbing Landscapes-as-Texts, „Australian Geographical Studies"1999, t. 37, nr 2, s. 130-141.

27 J.M. Rickly, The (Re)production of Climbing Space. Bodies, Gestures, Texts, „Cultural Geographies” 2017, t. 24, nr 1, s. 69-88.

28 T. Piotrowski, $W$ burzy i mrozie, s. 381.

29 Idem, Gdy krzepnie rtęć, Warszawa 1982. 
dla podmiotu jest przede wszystkim bycie u progu przygody górskiej, czym pragnie się podzielić. Otwarcie narracji pokazuje ów moment dziania się, nabierania tempa, oczekiwania i niepokoju. Następnie Piotrowski cofa się w czasie i odtwarza okoliczności organizacyjne. Prosty zabieg modyfikowania chronologii daje podwójny efekt: osobista relacja splata się z kronikarską rekonstrukcją, sytuując podmiot zarazem w centrum i na obrzeżach wydarzeń. „Ja” angażuje się, obnażając własny życiorys, lecz także kieruje się ku zdystansowanej obiektywizacji uporządkowanego relacjonowania. Podobna inwersja czasowa pojawia się zresztą w opowiadaniu Zima za Bonattim ${ }^{30}$, gdzie klamrę określają dwa punkty: pobyt w szpitalu i pomoc ratowników, oczywiście zasadnicza opowieść jest między nimi rozpięta. Daje to efekt zbliżony do struktury fabularnej kryminału operującego wnioskowaniem indukcyjnym. Piotrowski skupia uwagę na specyficznym dla alpinistów problemie odmrożeń, których boleśnie doświadczył. Chwyt ten, intrygując intymnością cielesnych dolegliwości, przybija tym samym stempel autentyczności usytuowanej w subiektywnym doświadczeniu wspinacza.

Pisanie górskie w przypadku Piotrowskiego ewoluowało „kolażowo”3I , co najwyraźniej wskazuje potrzeba „przepisania” tekstów norweskich. Pytania o przyczyny i skutki ponownego zredagowania tych opowieści, co sugeruje autorefleksyjny ruch w obrębie konceptów metaliterackich (lub szerzej: metadyskursywnych), stają się szczególnie ważne w kontekście ewentualnego przekształcania autobiografii jako istotnego komponentu własnych strategii dyskursywnych.

Teksty norweskie, stanowiące po prostu oddzielne i do pewnego stopnia rozproszone etapy życiorysu alpinisty, zostały finalnie zintegrowane $w$ jednej książce ${ }^{32}$. Wydaje się, że poza motywacją redakcyjną, aby stworzyć jednorodny tematycznie tom, można w tej decyzji doszukiwać się wyraźnego sygnału autorefleksyjnego. W perspektywie problematyki porządkowania doświadczeń podmiotu przez powtórnie przepracowane narracje gest integracji zyskuje również wymiar egzystencjalny: jest próbą skompilowania w określonym wycinku - własnego życiorysu, a zatem zintegrowaniem własnej tożsamości alpinisty ekstremalnego. Publikację opowieści norweskich determinowała chronologia przygód górskich. Początkowo były rozpisane na mniejsze historie, aby ostatecznie połączyć się w obrębie jednej spójnej tematycznie książki $W$ lodowym świecie Trolli, prezentującej pewną całość w biografii alpinistycznej Piotrowskiego. Całość ta jest także cenna jako szczegółowy dowód kompetencji wspinaczkowych, wzmacniający prawo do autobiogra-

30 Idem, W burzy i mrozie, s. 98-204.

31 Zob. M. Pacukiewicz, Natura alpinizmu. Wspinaczka jako „bricolage”, „Prace Kulturoznawcze” 2012, t. $14, \mathrm{nr} 2$.

32 T. Piotrowski, W lodowym świecie Trolli, Warszawa 1986. 
ficznego relacjonowania trudniejszych przygód górskich na siedmio- i ośmiotysięcznikach. Konstruowanie owej spójności dokonuje się przez wykreślenie mapy osiągnięć wspinaczki wysokogórskiej w rejonie Romsdalen w Romsdal, szkicu otwierającym tom. Piotrowski porządkuje informacje w trybie encyklopedycznym, tworząc historię zmagań wspinaczy z różnych rejonów świata ze skalnymi trudnościami norweskich gór. Wplata w ten przegląd polskie przygody górskie, informując jednocześnie, które $\mathrm{z}$ nich zostały opisane w opowiadaniach $\mathrm{w}$ dalszej części książki. Charakterystyczne jest w tym szkicu to, że traktuje siebie niemal beznamiętnie jako jednego z członków wielu wypraw alpinistycznych. Opowiadanie $W$ Ścianie Trolli, pierwotnie wydane samodzielnie, otwiera zbliżony stylistycznie wstęp, następnie usunięty ze zbioru $W$ lodowym świecie Trolli. Oba wprowadzenia różni istotny element. Tutaj ,ja” ujawnia się i na moment zdejmuje maskę quasi-neutralnego kronikarza, zdradzając własne zaangażowanie emocjonalne i sugerując autobiograficzne uwarunkowania opowieści, choć za chwilę znów wybierze bezosobową obiektywizację encyklopedysty, która określi pozostałą część tekstu:

\ Chcę zaprosić Czytelników do odbycia wspólnej wspinaczki poprzez jedną z najwyższych skalnych ścian Europy - Trollveggen (Ścianę Trolli), do przeżycia ekscytującej przygody, ryzykownej i niebezpiecznej, do spotkania ze skałą i lodem, wichrem i morzem, głodem i zmęczeniem, wreszcie z ogromną ulgą i szaloną radością w chwili zwycięstwa. Będzie to opowieść o zimowej wspinaczce, o jednym z najtrudniejszych przedsięwzięć polskiego alpinizmu ekstremalnego ${ }^{33}$.

Czesi dokonali pierwszego zimowego przejścia drogi angielskiej na Trollveggenie, której drugiemu przejściu w 1977 r. przez Wojciecha Jedlińskiego i Tadeusza Piotrowskiego poświęcona jest niniejsza książka. [...]

Zimowy alpinizm w Górach Skandynawskich rozkwitł na dobre. Wielka w tym zasługa pionierów z I972 roku: Andrzeja Dworaka, Wojciecha Jedlińskiego, Ryszarda Kowalewskiego i Tadeusza Piotrowskiego ${ }^{34}$. 
Ostatnia książka Naga Góra - Nanga Parbat ${ }^{35}$ stanowi pewien punkt dojścia poetyki Piotrowskiego, w której otwarte wyeksponowanie własnej podmiotowości okazuje się kluczowe. Tę ewolucję koncepcyjną wyraźnie widać w porównaniu wstępnych partii poszczególnych książek. Tworzy to niejako mimowolną kodę, interesującą w kontekście relacji między doświadczeniami Piotrowskiego a wypracowywanym dyskursem pisarskim i jego determinantami autobiograficznymi.

U stóp filara, otwierające Nagq Górę, jest właściwie „afektywną” historią poznawania i konceptualizowania miejsca, które z perspektywy autorskiego ,ja” wydaje się całkowicie odporne na podobne próby. Początek oparty na zabiegu antropomorfizacji góry kreuje aurę wrogiej niedostępności i tajemniczości, a w konsekwencji historia kolejnych heroicznych starań, aby zdobyć szczyt, ciąży wyraźnie ku ekspresji wzniosłości Nangi Parbat, tego - jak pisze Piotrowski - „klucza uruchamiającego wyobraźnię" ${ }^{36}$. Zresztą trudno oprzeć się wrażeniu zbieżności tej metafory z surrealistycznymi hasłami apologii wyobraźni. Po nakreśleniu tła przystępuje do rekonstrukcji osobistej relacji z górą, relacji naznaczonej fascynacją, przy czym siła przyciągania szczytu zostaje przez Piotrowskiego udramatyzowana. Figura Nangi - wpisana w siatkę szerszych zainteresowań alpinistycznych - wyziera spod warstwy innych wydarzeń. Historia nieoczywistego magnetyzmu góry, działającego niejako fatalistycznie na wspinacza, staje się chwytem budującym bliskość (między autorem-podmiotem i górą oraz między autorem a czytelnikiem prowokowanym do empatycznego uczestnictwa; w obu przypadkach ustanawia to niemal intymną bliskość) i obnażającym specyficzne pragnienia, osadzone w splocie poczucia niedostępności góry oraz marzeń o potencjalnych praktykach alpinistycznych, do jakich prowokuje jej istnienie.
》 [Nanga Parbat - P. K.] góra odległa w niewymiernej czasoprzestrzeni, że nawet marzyć o niej nie potrafiłem, bo znajdowała się, jak wszystkie inne góry dalekiego świata, poza granicami dostępnymi dla ówczesnej mojej wyobraźni. Upływały lata, a wraz z nimi zmieniała się moja optyka widzenia świata. [...] Zrodziły się więc i rojenia o Nagiej Górze - wciąż jednak nieziszczalne mrzonki, wydumania nieokiełznanej ima- ginacji. Raz nawet otarłem się o nią i byłem bliski [...] przekształcenia marzeń w rzeczywistość [...].

Nanga Parbat zobaczyłem dwa lata później. Jechałem pod Rakaposhi z wyprawą polsko-pakistańską. Drugiego dnia [...] ujrzałem wyła-

Ibidem, s. 6. 
niającą się spoza zwałów ciemnych chmur białą zjawę. [...] Nanga Parbat! Wyskoczyłem na pobocze drogi. Niewiele zobaczyłem [...].

Więcej szczęścia miałem rok później. [...] tym razem do Gilgitu lecieliśmy samolotem. [...] Rozłożysty masyw przesłonił sobą horyzont. Samolocik - teraz dopiero dało się odczuć jego maleńkość i kruszyznę - przemykał zaledwie u jej stóp. Obraz góry wypełniał widziany przez iluminator świat. Przytłaczał [...].

Jeden list odmienił nagle wszystko. Karl Herrligkoffer, człowiek chyba najbardziej związany emocjonalnie z Nanga Parbat, wystosował do Polskiego Związku Alpinizmu zaproszenie dla dwóch osób do udziału w ekspedycji na południowo-wschodni filar Nagiej Góry [...].

Teraz miałem ją przed oczami, tuż przed sobą. Stałem z wysoko zadartą głową i gapiłem się oniemiały z wrażenia na jej kolosalną sylwetkę 37 .

4 .

Alpinista, przepisując przestrzenno-cielesne doświadczenia, korzysta z intertekstowych filtrów, które pozwalają mu zrealizować sprzeczne na pierwszy rzut oka teleologie - ukonstytuować własny idiom oraz umieścić swoje pisanie w płaszczyźnie aktywności górskich (zwłaszcza wspinaczki wysokogórskiej) jako ponadjednostkowych praktyk kulturowych oraz jako określonej literatury, odmiennej od głównego nurtu, choć przecinającej się z nim w pewnych punktach. Umieszczanie własnej opowieści w siatce literatury górskiej służy wykreśleniu mapy wspólnoty, naszkicowaniu tła, które zapewnia skalę porównawczą. Osiągnięcia wspinaczkowe są częścią czegoś większego, ponadjednostkowego - pewnej obsesji eksploracji i wyczynu sportowego (ekstremalnego). „Ja” wyraża siebie, ale jako „efekt” wspólnoty namiętności górołazów i wspinaczy $3^{38}$. Dochodzi do mediacji między wspinaczem i niewspinaczami, ale też między wspinaczem i jego środowiskiem społecznym.

Tekst narracji górskiej rodzi się w drodze (pozornie) wyraźnego i kategorycznego rozstrzygnięcia dylematów wynikających z opozycji fikcyjne - niefikcyjne

37 Ibidem, s. 6-9.

38 S. Smith, J. Watson, Reading Autobiography..., s. 19-21. 
i literackie - dokumentalne ${ }^{39}$. Ekspresja ,ja” jest więc uzależniona od niefikcyjnej, dokumentalnej relacji podróżniczej i wspinaczkowej. Taka oczywista gwarancja szczerości i autentyczności, będąca pochodną wyboru jednej strony wykluczających się alternatyw, umocowana jest głębiej w modernistycznym pragnieniu wyrażalności tego, co unikalne, osobiste, jednostkowe, lecz z konieczności zapośredniczone przez ponadjednostkowe narzędzia porozumienia: język, narrację, retorykę czy dyskurs ${ }^{40}$. Daje to o sobie znać w pisaniu Piotrowskiego, manifestując się w różnych aspektach: stylistycznym, kompozycyjnym, poetologicznym, gatunkowym.

Opowieść górska Tadeusza Piotrowskiego rozpatrywana w kategorii literatury dokumentu osobistego jest kontaminacją, ulokowaną nie tylko na pograniczu gatunków dokumentalnych, ale też na przecięciu dyskursów literackich i nieliterackich oscylujących wokół autentyczności ${ }^{4 \mathrm{I}}$. Taka hybryda rzutuje na postać tożsamości wyłaniającej się z tekstu, choć działa to również w drugą stronę. Pytania o to, kim jest Tadeusz Piotrowski, a także w jakie role wchodzi tekstowe „ja”, pozwalają myśleć o hybrydyczności jako celowym działaniu międzytekstowym. „Ja” przełącza się między trybami profesjonalisty i popularyzatora: specjalistyczna wiedza i w konsekwencji określone rozwiązania narracyjno-stylistyczne (eksponowanie pojęć i terminów wspinaczkowych, rozległe opisy formacji skalnych jako możliwych przestrzeni wertykalnego ruchu alpinisty, operowanie schematem fabularnym chronologii wyprawy) są kontrowane przez osobiste doświadczenia domagające się szerzej zrozumiałych konwencji i chwytów, znanych z dyskursów literackich (porównania, wyjaśnienia, analogie z tym, co poza alpinizmem, subiektywizacja właściwa dziennikowi lub pamiętnikowi, inwersje czasowe i asocjacje, kolaż).

Narrator opowieści górskich Piotrowskiego funkcjonuje na dwóch warunkujących się płaszczyznach. Autor pozostaje wewnątrz i na zewnątrz opowieści, próbując pogodzić zderzające się modalności. Odgrywa rolę medium, instancji porządkującej całość, dbającej o spójność i ciągłość. Jest też autobiograficznym „ja”, które opowiada siebie. To rozszczepienie staje się widoczne w takich momentach narracji, które kreślą szerszy kontekst, mający charakter albo encyklopedycznego wprowadzenia wypełniającego luki faktograficzne, albo rekonstruowania wydarzeń, w których ,ja” nie brało bezpośrednio udziału. Widać to także w nieco mniej oczywistej sferze.

Zdjęcia umieszczono w poszczególnych książkach, aby zilustrować trudną do uchwycenia w trybie czysto dyskursywnym specyfikę wyprawy i wspinaczki, a tym

39 Zob. A. Chomiuk, Fiction czy non-fiction? Uwagi na marginesie pewnego sporu, „Białostockie Studia Literaturoznawcze" 2013, nr 4, s. 233-249.

40 R. Nycz, Język modernizmu. Prolegomena historycznoliterackie, Wrocław 1997.

41 M. Warchala, Autentyczność i nowwoczesność. Idea autentyczności od Rousseau do Freuda, Kraków 2006. 
samym, aby zminimalizować dysonans między konkretnością praktyk alpinistycznych i ich tekstowym zapośredniczeniem. Zostały odpowiednio opisane. Znamienne natomiast staje się to, że właśnie w obrębie tych podpisów i dokumentarnej własności fotografii nasila się problem tożsamości i nietożsamości „ja” na pozór bezsprzecznie autobiograficznych tekstów. Podpisy, jakimi opatrzono zdjęcia, są zaskakująco niekonsekwentne. Zwykle w trybie obiektywizacji opisują postaci wspinaczy, w tym Piotrowskiego, co sprawia osobliwe wrażenie, że autor traktuje siebie akurat w sferze ikonograficznej jako jednego z bohaterów własnej narracji, stając na zewnątrz swojego doświadczenia. Inne podpisy są z kolei „pierwszoosobowe”, co harmonizuje z zasadniczo osobistą tonacją poszczególnych tekstów - dominuje perspektywa wewnętrzna z właściwą jej logiką rekonstrukcji przeżyć. Schizofrenia tego rodzaju oczywiście mogłaby zostać złożona na karb niekonsekwentnej i niezdarnej redakcji, lecz w obliczu wspomnianego przeze mnie rozszczepienia konceptualnego w ramach instancji nadawczo-porządkującej i narracyjnej - ta nieścisłość pozostaje znakiem niejednorodnego fundamentu autobiograficznego prozy alpinistycznej.

Autobiografia rodzi się „przy okazji”, to znaczy na marginesie zasadniczego celu wyrażenia doświadczeń, przeżyć i afektów w obliczu góry, ściany czy szczytu, przezwyciężenia komunikacyjnego oporu. Zarazem pozostaje nieodzowna i nieusuwalna. Książki Piotrowskiego w kontekście polskich publikacji wyprawowych z lat trzydziestych XX wieku, szczególnie Stońce nad Tiricz Mirem i Naga Góra - Nanga Parbat, ale też wcześniejsze Gdy krzepnie rtę́, dowodzą istotnego przesunięcia w strategii narracyjnej. Dyskurs Piotrowskiego charakteryzuje się mniejszą skłonnością do tego, co można określić jako instytucjonalna obiektywizacja, obecna na przykład w oficjalnych książkach i relacjach prasowych z polskich wypraw alpinistyczno-eksploracyjnych w Andy na przełomie lat 1933-1934 oraz 1936-1937 $7^{42}$. Wyprawa przestaje funkcjonować przede wszystkim w kategorii instytucji, choć nadal jest pojmowana jako zbiorowy wysiłek, natomiast nie potrzebuje uzasadnień poza samą eksploracją sportową, dodatkowo równie ważne (a nawet ważniejsze) stają się subiektywne motywacje. Mimo to Piotrowski nie rezygnuje zupełnie z wprowadzania dystansu narracyjnego, co widać właśnie we wspominanych podpisach do fotografii. Komponent autobiograficzny, chociaż pozornie uboczny, pozostaje gwarantem szczerości, a w konsekwencji autentyczności narracji widzianej z dwóch perspektyw: innego alpinisty (potencjalnej instancji weryfikującej informacje i prawdopodobieństwo zdarzeń) i laika (dla którego autobiograficzny stempel stanowi wyłączną rękojmię opowieści). 
Autobiografia Piotrowskiego jest raczej efektem strategii szczerości, „produktem ubocznym”, ze względu na własną fragmentaryczność i procesualność, mających dwie podstawowe przyczyny. Po pierwsze, praktyczny wymiar wspinaczki zderza się ze swoim niedoskonałym odpowiednikiem tekstowym, doprowadzając podmiot (jako instancję kontrolującą adekwatność i odpowiedniość własnej reprezentacji doświadczeń) do konieczności niwelowania potencjalnych pęknięć i niespójności, choć takowe muszą się zdarzać z uwagi na charakter praktyki alpinistycznej, szczególnie w zimowym wariancie. Po drugie, rekapitulacja wspinaczkowej egzystencji dokonuje się zawsze ex post (znakomicie pokazuje to przypadek nieukończonej opowieści pod tytułem Naga Góra), ale zasadniczym impulsem pisania nie jest intencja podsumowywania i porządkowania własnego biosu. „Ja" zanurzone w wertykalnej przestrzeni zdaje relację ze swojego doświadczenia ${ }^{43}$, zatem kształt podmiotu, jaki się wyłania z takiej opowieści, jest konsekwencją innego celu - opowiedzenia o tym, co istnieje poza ludzką podmiotowością, a następnie tego, jak owa zewnętrzność formuje podmiot. Spójna wizja ,ja” jawi się jako koherentna całość tylko dlatego, że względnie uporządkowana okazuje się sama opowieść górska o byciu w przestrzeni.

Intertekstowe filary alpinistycznego ,ja”, z których korzysta podmiot i które wzmacniają jego autoportret, stanowią: podobne teksty górskie innych alpinistów ${ }^{44}$ (Waltera Bonattiego, Kurta Diembergera, Maurice'a Herzoga, Hermanna Buhla), ale także ślady lektur tekstów literackich (Goethego, romantyków, Tolkiena czy Andrzejewskiego z Miazgq, domykającą przekształcenia w polskiej prozie nowoczesnej). Wyznaczają rezerwuar narzędzi opisu i możliwych narracji, potrzebnych, by wyrazić doświadczenie wertykalnego bycia. Piotrowski kontaminuje gatunki, ponieważ nie może postępować inaczej, jeśli ma utrzymać względną równowagę między inwencją niezbędną, by zachować własną idiomatyczność, a konwencjonalnością oferującą porozumienie z czytelnikiem (laikiem lub specjalistą). Książka wyprawowa i dziennik wyprawy spotykają się z notatnikiem i dziennikiem osobistym. Płaszczyzną, na którą autor rzutuje swoje opowieści, jest zaś nie tylko pisarstwo górskie i osobiste, ale również szeroko pojęta literatura podróżnicza i reportaż. Te gatunki i tryby są podobne, ale jednocześnie odmienne w kluczowych dla siebie aspektach, na przykład w sposobach ujmowania figury autorskiego ,ja”. To rozwiązanie znajduje pragmatyczne uzasadnienie, choć jest to wyłącznie swego rodzaju zastępcza kompatybilność. Operowanie przez Piotrowskiego rozmaitymi mechanizmami narracyjno-stylistycznymi w zależności od potrzeb jest reakcją na hybry-

43 N. Lewis, The Climbing Body, Nature and the Experience of Modernity, „Body and Society” 2000, nr 6, s. 58-80.

44 Por. M. Okupnik, Autobiografie polskich sportowców..., s. 154-155. 
dowość góry bądź ściany skalnej: liczne formacje skalne i lodowe, zmienne kąty nachylenia, pogoda, odmiany śniegu, warunki lodowe, otoczenie danej góry sprawiają, że szczyt będący obiektem zainteresowania wspinacza nie jest monolitycznym tworem, którego można doświadczyć przez jedną formę aktywności lub jedną technikę poruszania się ${ }^{45}$. Jeżeli każda góra jest podobna, a zarazem zmienna w stosunku do dotychczasowych przestrzeni górskich, to pisanie również powinno - jeśli ma podjąć próbę sprostania pragmatyce wertykalnego bycia alpinisty - realizować analogiczną zmienność. Byłoby to także spójne z przekształceniami „ja”, konstruującego równolegle własną tożsamość.

5 .

Proza Piotrowskiego jest oczywiście autobiograficzna i jednocześnie taka nie jest ${ }^{46}$. Szczególnie w kontekście stwierdzenia, że autobiografia umyka wyraźnym definicjom jako permanentnie sprzeczny tryb pisania i czytania, który uchyla kryterium prawdziwości - fałszywości ${ }^{47}$.

Pisanie Piotrowskiego - które mierzy się z problemem doświadczanej realności otwarcie, sięgając po „literackość” ${ }^{8}$, w przeciwieństwie do rozmaitych form dokumentacji wyczynów alpinistycznych osuwających się w automatyzmy konwencji schematyzujących obcowanie z przestrzenią wertykalną ${ }^{49}$ - nieustannie zmaga się z własnymi uwarunkowaniami i ambicjami. Nie może pogodzić sprzeczności wynikających z pragnienia ekspresji, potwierdzania praw do snucia opowieści i zapewnienia narzędzi ich (zarówno pragnień, jak i praw) weryfikacji. W tym przypadku autobiografia jako rodzaj umowy nakłada etyczne zobowiązania, z których właściwie nie sposób się wywiązać. Szczerość, pozostająca gwarantem tejże umowy, musi okazać się strategią, tekstowym konstruktem, który nie będzie dostarczycielem weryfikowalnej wiedzy i sprawdzalnych informacji, skoro taka autentykacja może mieć wyłącznie fundament w subiektywnej podmiotowości ${ }^{\circ}$. Szczerość

45 Por. P. Barratt, Vertical Worlds. Technology, Hybridity and the Climbing Body, „Social \& Cultural Geography" 2011, t. 12, nr 4, s. 397-412.

46 Por. L.A. Renza, Wyobraźnia stawia veto. Teoria autobiografi, tłum. M. Orkan-Łęcki, w: Autobiografia, red. M. Czermińska.

47 P. de Man, Autobiografia jako od-twarzanie, tłum. M.B. Fedewicz, „Pamiętnik Literacki” 1986, t. 77, nr 2, s. 307-318.

48 Por. M. Głowiński, Dokument jako powieśc, w: idem, Narracje literackie i nieliterackie, Kraków 1997, s. 125-142; M. Okupnik, Autobiografie polskich sportowców..., s. 151.

49 J. Kolbuszewski, Quo vadis, literaturo górska?, „Taternik” 1961, t. 37, nr 1, s. 23-24.

50 Zob. L. Trilling, Sincerity and Authenticity, Cambridge 1972. 
bowiem umieszczona $\mathrm{w}$ centrum szkieletu autobiograficznego, pozostaje - jak sama autobiografia - figurą tekstową, istniejącą przez językowe reprezentacje, potwierdzającą własne istnienie poprzez performatywne chwyty ${ }^{5 \mathrm{I}}$, w tym przypadku odsyłające poza porządek opowieści, uwidaczniające się choćby w encyklopedyzmie Piotrowskiego. Idiomatyczność - komponent strategii szczerości, koncepcyjny element autentyczności - musi prowadzić do poszukiwania takiego trybu mówienia, które będzie adekwatne z perspektywy podmiotu, ale równocześnie doprowadzi do „nadmiernej” literackości - proste rejestrowanie faktów jest wszak niewystarczające. Zbytnia literackość autobiografii alpinistycznej, co przecież Piotrowski kontruje dzięki różnym obiektywizacjom (na przykład depersonifikacji), byłaby ujawieniem sprzecznego statusu autobiografii. Czy zatem można myśleć o alpinistycznym pisaniu górskim nieco inaczej niż w kategorii ufikcyjnionej autobiografii lub dokumentu zbliżonego do literatury?

Topografia (a właściwie tekstowa i fotograficzna reprezentacja topografii) i autobiografia określają się przez nierozerwalny splot, co prowadzi do dość ryzykownego, choć także atrakcyjnego wniosku, że opis przestrzeni jest opisem siebie, zaś przestrzeń nie może zaistnieć pozbawiona ludzkiej autorefleksyjnej obecności konstytuującej się w opowieści. Narracja górska, zdeterminowana pozatekstową przestrzenią, musi funkcjonować przez relokacyjne powtórzenie podmiotu w materii tekstowej. Doświadczanie przestrzeni górskiej jest dialektycznie sprzężone z biosem alpinisty, zaś opisywanie i ewokowanie tego doświadczenia, a przede wszystkim specyficznego statusu inicjującej i utrzymującej je praktyki sprawiają, że proza górska jako autobiografia tkwi w środku definicyjnej aporii ${ }^{52}$, ale poniekąd przechodzi nad tym z pewną obojętnością. Jest permanentnym powtórzeniem ruchu, cielesnej obecności w obliczu przestrzeni, staje się osobliwie dokumentalna, choć nie może w pełni uzasadnić obiektu, jaki przyszło jej utrwalić, z uwagi na status tegoż obiektu: ujęzykowionej reprezentacji doświadczenia i pozajęzykowej praktyki taktylno-przestrzennej.

Teksty Piotrowskiego są ciekawymi przekładami procesu mediacji między wysłowieniem przestrzennej izolacji oraz społeczną izolacją alpinizmu jako „niezrozumiałej” praktyki a szerokim gronem „normalnych” czytelników. Jego opowieści górskie są formami przezwyciężania pewnej wsobności alpinistycznego „ja”, skupionego na wspinaczkowej praxis jako głównym celu, usuwającym z pola widzenia wszystko, co nie mieści się w jej obszarze. Alpinista, snując własną narrację, działa egoistycznie w dwojakim sensie: pragnie zintegrować swoje doświadczenie, ale

51 Por. Y. Horsman, Narrative and Confessions in J.M. Coetzee's "Disgrace" and "The Lives of Animals", w: The Rhetoric of Sincerity.

52 Por. L.A. Renza, Wyobraźnia stawia veto..., s. 81-82. 
także - popularyzatorsko lub niemal dydaktycznie - pozwala „profanom” zajrzeć do wnętrza elitarnej wspinaczki. Pośredniczy między próbami zrozumienia swoich aktywności i swojej podmiotowości oraz wysłowieniem społecznie „nieprzejrzystej” praktyki alpinistycznej.

\section{Bibliografia PODMIOTOWA}

Piotrowski T., Gdy krzepnie rtęć, Warszawa 1982.

Naga Góra - Nanga Parbat, Warszawa 1990.

W burzy i mrozie, Warszawa 1977.

W lodowym świecie Trolli, Warszawa 1986.

WŚcianie Trolli, Warszawa 1984.

\section{BIBLIOGRAFIA PRZEDMIOTOWA}

Alphen E. van, Bal M., Introduction, w: The Rhetoric of Sincerity, red. E. van Alphen, M. Bal, C.E. Smith, Stanford 2009.

Barratt P., Vertical Worlds. Technology, Hybridity and the Climbing Body, „Social \& Cultural Geography” 2011, t. 12, nr 4.

Beaujour M., Autobiografia i autoportret, tłum. K. Falicka, w: Autobiografia, red. M. Czermińska, Gdańsk 2009.

Chomiuk A., Fiction czy non-fiction? Uwagi na marginesie pewnego sporu, „Białostockie Studia Literaturoznawcze" 2013, nr 4.

Colley A.C., Victorians in the Mountains. Sinking the Sublime, London 2010.

Daszyński S., Polska wyprawa alpinistyczno-naukowa w góry Ameryki Potudniowej, „Wierchy” 1934, nr 12.

Davis W., Into the Silence. The Great War, Mallory, and the Conquest of Everest, New York 2012.

Głowiński M., Narracje literackie i nieliterackie, Kraków 1997.

Hołata D., O pochodzeniu ksiązki wyprawowej, „Bularz” 1991.

Horsman Y., Narrative and Confessions in J.M. Coetzee's "Disgrace" and "The Lives of Animals", w: The Rhetoric of Sincerity, red. E. van Alphen, M. Bal, C.E. Smith, Stanford 2009.

Isserman M., Weaver S.A., Upadek olbrzymów. Historia wspinaczek himalajskich od epoki imperiów do epoki skrajności, tłum. M. Młynarz, Oświęcim 2019.

Jarzębowski H., Bajdurzyć, czyli mówić prawdę, „Góry” 2013, nr 9 (232).

Kolbuszewski J., Góry-przestrzenie i krajobrazy. Studia z historii literatury i kultury, Kraków 2020.

Literatura i Tatry. Studia i szkice, Zakopane 2016.

Quo vadis, literaturo górska?, „Taternik”1961, t. 37, nr 1.

Tatry w literaturze polskiej. Cz. 1-2, Kraków 1982.

Lejeune P., Wariacje na temat perwnego paktu. O autobiografii, red. R. Lubas-Bartoszyńska, tłum. W. Grajewski et al., Kraków 2007.

Lester J., Spirit, Identity, and Self in Mountaineering, ,Journal of Humanistic Psychology” 2004, t. 44, nr 1. Lewis N., The Climbing Body, Nature and the Experience of Modernity, „Body and Society” 2000, nr 6. 
Macfarlane R., Mountains of the Mind. A History of a Fascination, London 2018.

Mallory G., Climbing Mount Everest Is Work for Supermen [wywiad], „The New York Times”, 18 marca 1923.

Man P. de, Autobiografia jako od-twarzanie, tłum. M.B. Fedewicz, „Pamiętnik Literacki” 1986, nr 2.

Marek A., Andy jako rejon eksploracji górskiej Polaków do 1989 r., „Słupskie Prace Geograficzne” 2013, nr 13 .

Matuszyk A., Czy ideologia jest koniecznie do wspinania potrzebna? (Kilka stów o istocie i funkcjach ideologii wspinaczkowych), w: Materiaty z teorii i dydaktyki sportów wspinaczkowych. Z. 2, red. A. Matuszyk, Kraków 1993.

Mazzolini E., The Everest Effect. Nature, Culture, Ideology, Tuscaloosa 2015.

Milnes T., Sinanan K., Introduction, w: Romanticism, Sincerity and Authenticity, red. T. Milnes, K. Sinanan, London 2010.

Nettlefold P.A., Stratford E., The Production of Climbing Landscapes-as-Texts, „Australian Geographical Studies" 1999, t. 37, nr 2.

Nycz R., Jezzyk modernizmu. Prolegomena historycznoliterackie, Wrocław 1997.

Okupnik M., Autobiografie polskich sportowców samotników, Gniezno 2005.

Pacukiewicz M., Grań kultury. Transgresje alpinizmu, Kraków-Katowice 2012.

Literatura alpinistyczna jako „sobapisanie”, „Napis” 2010, seria 16.

Natura alpinizmu. Wspinaczka jako „bricolage”, „Prace Kulturoznawcze”2012, t. 14, nr 2.

Renza L.A., Wyobraźnia stawia veto. Teoria autobiografi, tłum. M. Orkan-Łęcki, w: Autobiografia, red. M. Czermińska, Gdańsk 2009.

Rickly J.M., The (Re)production of Climbing Space. Bodies, Gestures, Texts, „Cultural Geographies” 2017, t. $24, \mathrm{nr} 1$.

Roszkowska E., Taternictwo polskie. Geneza i rozwój do 1914 roku, Kraków 2013.

Smith S., Watson J., Reading Autobiography. A Guide for Interpreting Life Narratives, Minneapolis-London 2001.

Stępień T., Przestrzeń w literaturze „górskiej”, w: Od poetyki przestrzeni do geopoetyki, red. E. Konończuk, E. Sidoruk, Białystok 2012.

Trilling L., Sincerity and Authenticity, Cambridge 1972.

Tumidajewicz Z., ... o polskiej literaturze alpinistycznej, „Bularz” 1991.

Warchala M., Autentycznośc i nowoczesnośc. Idea autentyczności od Rousseau do Freuda, Kraków 2006.

Wojsznis J.T., Druga polska wyprawa w Andy 1936/37 r. w potudniowa częśc Puna de Atacama. Opis wyprawy, „Taternik” 1956, t. 32, nr 3/4.

SŁowA KLUCzE: alpinizm, biografia, nowoczesność, Tadeusz Piotrowski, himalaizm

\section{Vertical Isolation. Mountaineering Writings of Tadeusz Piotrowski}

The article is concerned with the writings of the Polish mountaineer, Tadeusz Piotrowski. The author considers the relationship between the experiences of ver- 
tical space, plot and subjectivity. He analyses Piotrowski's writing, in an attempt at identifying characteristic elements of the climber's discourse in the context of sincerity and autobiographical narrative. Tadeusz Piotrowski's story is defined by modernity, accumulating in 'the Self' the subsequent paradoxes resulting from contradictions within key concepts of truth, authenticity and sincerity. The climber's discourse tries to reconcile the desire to repeat the vertical movement within textual representation, and the idiomatic expression of the subject. The text exposes the paradoxical status of the autobiography situated beyond truth and falsehood, while, at the same time, remaining the most effective tool for communicating mountaineering experiences.

KEY words: alpinism, biography, modernity, Tadeusz Piotrowski, mountaineering 